\title{
Analysing the innovation process in the EU Integrated Programme, ISAFRUIT
}

\author{
By BEGOÑA DE LA CALLE ${ }^{1 *}$, JILL STANLEY ${ }^{2}$ and AGUSTÍN FONTS ${ }^{1}$ \\ ${ }^{1}$ Institut de Recerca i Tecnologies Agroalimentaries, Passeig de Gràcia 44 3ª, 08007 Barcelona, Spain \\ ${ }^{2}$ The New Zealand Institute for Plant and Food Research Limited, 990 Earnscleugh Road, RD 1, \\ Alexandra 9320, New Zealand \\ (e-mail: Begona.delacalle@irta.cat) \\ (Accepted 1 September 2009)
}

\begin{abstract}
SUMMARY
ISAFRUIT is an integrated European Union Project focussed on increasing fruit consumption as a means to improve human health, through evaluating the fruit chain and addressing bottlenecks therein. The innovations which are being developed throughout the ISAFRUIT Project have been analysed to determine both the success factors and the obstacles in reaching the commercialisation stage. Only $9.58 \%$ of the deliverables planned within the Project were focussed on developing technological innovations. There is evidence, however, of successes in the development of new innovations arising from the ISAFRUIT Project, with several other potential innovations in the pipeline. Of the technologies identified, $67 \%$ are still at the "invention stage"; that is, the stage prior to bridging the so-called "valley of death", the stage between an invention and an innovation. Those which are considered to have moved over the "valley of death" either had industry partners included in the Project, or had consulted with industry to ensure that the technology was relevant, or met a recognised industry need. Many of the technologies which made less progress did not have the same interactions with industry. A number of other issues were identified which prevented further progress towards innovation. The need for scientists to publish scientific papers, both for their career pathways and to increase their chances of future funding, was identified as one issue, although the filing of patents is now becoming more accepted and recognised. The patenting system is considered complex by many scientists and is not well-understood. Finally, agreements between partners on the sharing of intellectual property rights can cause a delay in the innovation process.
\end{abstract}

SAFRUIT is an integrated European Union Project which commenced in January 2006 and will finish in June 2010. The main strategic objective of ISAFRUIT was to increase fruit consumption, to improve the health and well-being of Europeans, and their environment, by taking a total chain approach, identifying the bottlenecks and addressing them by a better understanding of consumer-driven preferences. The Project encompassed the total fruit chain, from fork-to-farm, starting with identifying consumer needs and working back through the chain to solve the issues identified. From the beginning, the Project identified the need to ensure the dissemination of knowledge by a number of methods, depending on the nature of the knowledg. A unique Pillar (i.e., a project area within the research programme) was established, specifically to assist with this. One Work-package (i.e., sub-project) within this Pillar was focussed on increasing the impact of innovations.

There are many definitions of innovation, but, in general, it is agreed that bringing an idea to the market involves two different steps. Invention is the generation of a process or technology. Innovation occurs when this idea is developed and put into practice or, from a business point of view, is commercialised (Heanue, 2008). Other definitions state that innovation must create

*Author for correspondence. added-value, either directly for the enterprise, or indirectly for its customers, and/or that innovation is something which is new or significantly improved from what was available previously (Rogers, 1998).

Branscomb and Auerswald (2002) and Marczewski (1997) divide the process from invention to innovation into five Stages (Figure 1). From Stage 3, if the potential product is sufficiently promising to attract capital investment, then the final production and marketing Stages (Stages 4 and 5) can be initiated. At the end of Stage 4, the product is introduced into the marketplace, and an innovation has then taken place. During Stage 5, investors can anticipate the start of returns on their investments.

The "valley of death" (between Stages 2 and 3) is a widely-used concept during the evolution from an invention to an innovation. It is a step where inventions often fail to be commercialised because of factors such as

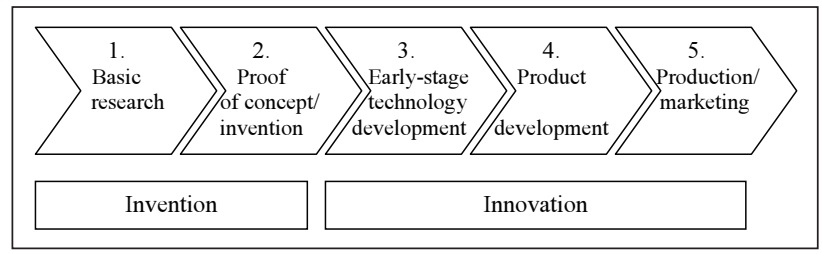

FIG. 1

The process from invention to innovation, as described by Branscomb and Auerswald (2002). 
a lack of funding or lack of a "champion" to develop the prototype into a final product or technology (Marczewski, 1997; Markham, 2002; Wessner, 2005). Markham (2002) defined the "valley of death" as the gap between a technical invention or market recognition of an idea, and efforts to commercialise it.

One of the explanations for this gap is that the first Stage of the process (basic research) is funded by Government and motivated by societal goals such as promoting environmental quality and/or consumer health (i.e., many of the goals of the ISAFRUIT Project). However at the final Stage, where the driving force is to develop a technology that will be of interest to consumers, the technology needs private funding to reach the market (Marczewski, 1997). Most innovations fail due to the absence of such external support, or because they are not sufficiently well oriented to consumer needs (Kalanje, 2005).

Markham (2002) stated that one of the reasons for the existence of the "valley of death" was that scientists and commercial managers have different concerns and objectives. While scientists are motivated by discovery and pushing back the frontiers of knowledge, commercial managers need a product to sell, and often consider the value of "simple" discovery to be theoretical or useless.

Taylor and Barrett (1997) exposed two factors that make it difficult to develop basic research into a commercially-viable innovation. One was the obligation of research institutes and their staff to make the results of publicly-funded research freely available to all interested parties and the public. The second issue arises from the conflict between assisting the career development of young scientists by encouraging rapid and open scientific publication, and the commercial protection of proprietary knowledge through patents.

Most innovative ideas never reach the market (Marczewski, 1997) because they cannot cross the "valley of death", but those protected by some form of intellectual property (IP) method, stand a better chance (Kalanje, 2005).

The World Intellectual Property Organisation divides IP into two categories: industrial property, which includes patents, trademarks, industrial designs, and geographic indications of source; and copyright, which includes literary and artistic works such as novels, poems and plays, films, musical works, artistic works, and architectural designs (Anon, 2009a).

Not all inventions are patented, and some inventions are protected using alternative methods (Archibugi, 1992). Some inventions cannot be patented because they have to fulfil the criteria of utility, novelty, inventive step, and industrial applicability; but they can still be protected by trade secrets. Trade secrets can protect any form of confidential information, not just inventions (Daizadeh $e t$ al., 2002). A trade secret means all the secret information important for the functioning of a Company (Daizadeh $e t$ al., 2002). This can include any technical, technological, or knowledge and experience of a commercial and managerial character (e.g., lists of customers, information about contracts the entrepreneur has signed, company strategy, or its financial situation; Anon, 2009b). Probably one of the greatest example of a trade secret is the recipe for Coca Cola ${ }^{\circledR}$.
Kalanje (2005) identified that the ownership of a patent or a trade secret is helpful when attracting venture capital to develop the innovation. To maintain the competitive advantage of the final product, competitors should not have access to any vital information, if it has not been protected by other means.

Why do companies adopt innovation? In the Oslo Manual (OECD, 1997), several objectives that motivate companies to innovate are described: for example, to replace products that are being phased-out, to extend a product range, to develop environmentally-friendly products, to maintain market share, to increase market share, to open-up new markets, to improve production costs, to improve product quality, to improve working conditions, or to reduce environmental damage.

In general, most of the planned outputs from ISAFRUIT were expected to deliver scientific knowledge or to provide knowledge that could be shared publicly, to help motivate consumers to eat fruit for personal health purposes. A few tasks were designed to develop prototypes or new fruit products, processes or technologies within Work-packages that were more focussed on technological developments, especially in fruit processing and throughout the grower chain.

The objective of this paper is to analyse the processes of innovation in ISAFRUIT and to discuss the success factors and the obstacles that partners in ISAFRUIT encountered when converting inventions into business benefit.

\section{MATERIALS AND METHODS}

Annex 1 of the ISAFRUIT Project provided a detailed description of the tasks to be developed and the deliverables promised by each Pillar. The lists of deliverables promised by the Pillars within ISAFRUIT have been classified into one of three categories:

1) Deliverables focussed on the generation of scientific knowledge for further research use.

2) Deliverables focussed on disseminating information of interest to consumers, producers and politicians.

3) Deliverables focussed on industrial applications (i.e., intermediate deliverables, and final product or process deliverables).

It was sometimes difficult to decide which category to allocate some deliverables to, therefore a best estimate of category was made using the information available.

Deliverables falling into the third category above have been analysed further for their potential to reach the market. Some potential innovations were identified from the descriptions given in Annex 1. In addition, a survey was launched to ISAFRUIT Work-package leaders in order to detect which activities within ISAFRUIT were considered, by the researchers themselves, to have potential to be commercially exploited.

One way to measure the "innovation impact" of a Project is to measure innovation using the indicators proposed by Rogers (1998). The output measurements for innovation (Rogers, 1998) are:

- Introduction of new or improved product(s) or process(es)

- Percentage of sales from new/improved product(s) or process(es)

- Intellectual property statistics

- Company performance. 
However, in ISAFRUIT, it is still too early to apply such measurements. Therefore we categorised why we have categorised each deliverable according to the following output scheme:

1) Exploitation model

2) Innovation phase

3) Added-value

Each potential innovation was analysed in order to determine its exploitation model, innovation phase, and/ or added-value. The success or failure of each identified activity to develop into a commercially-viable innovation was assessed, and the reasons for the conclusions were discussed.

\section{RESULTS}

The deliverables promised in each Pillar of ISAFRUIT were classified into one of the three output categories above. The values for each Work-package and for each category are shown in Table I. Overall, 79.86\% of the deliverables promised were planned to add to scientific knowledge, $10.56 \%$ were planned to provide information for consumer, grower, or political interests, and $9.58 \%$ were focussed on developing innovations with industrial application.

From the deliverables claimed to have industrial application, and taking into account the survey results mentioned above, the following ten potential innovations were identified:

\section{New fruit products with added nutraceuticals using} freeze-chill and vacuum processing

Fresh-cut apple slices: Methods have been developed to prepare fresh-cut apple slices with added calcium, in a highly bio-available form, and a prebiotic, thus making the slices into a functional food.

Apple purée dessert: Methods have been developed to prepare apple purée containing a prebiotic material and a dietary fibre.

Some of these products have attracted venture capital, and have been introduced into the market.

\section{New fruit products using microwave processing}

Desserts have been developed with additional natural ingredients that are cooked and pasteurised using a semi-industrial microwave tunnel. This invention has not been commercialised as further investigation of this technology is required. Research has focussed on the production of a scientific paper. Research on the application of microwave radiation to food products has been done mainly by commercial laboratories, resulting in confidential data that are not published in peerreviewed journals. Nevertheless, this is an important contribution from ISAFRUIT to science.

New fruit products using high pressure processing

A process has been developed, and is ready to be scaled-up to an industrial level, which will preserve the quality and enhance the microbial stability of fruit, fruit preparations, and desserts using high pressure technology (HPP). This will be combined with new packaging. This technology could be commercialised and is currently being evaluated for commercial exploitation by a commercial company involved in the ISAFRUIT Project.

\section{Alternative techniques to reduce food-borne pathogens}

To ensure the microbial safety of minimally-processed fruits (mainly apple and peach), a process to eliminate or reduce food-borne pathogens using microorganisms isolated from fresh fruit (biocontrol agents) alone, or in combination with other techniques such as microwave radiation, high pressure treatments, or the addition of GRAS (i.e., Generally Regarded As Safe) substances will be developed. If a new bio-control agent is identified, its use will be protected.

\section{Prototype of a decision-support system for fruit quality management}

The "PeaPle" Decision Support System (DSS) was planned as a multi-cultivar system for apples and peaches which allows the user to design various supply chains from harvest to retail, with the technological parameters (e.g., duration, temperature, type of atmosphere, etc) set by the user. The first quality parameter modelled for this DSS was fruit firmness, but more quality indices will be modelled (e.g., soluble solids content, total acidity, or skin colour).

A successful DSS has been developed for decisions along the fruit supply chain. However, the model, which predicts quality changes, can only be applied to certain cultivars. More research is required to extend this model to a larger number of commercial fruit varieties before the system would be of commercial interest. This DSS may also be of interest to others such as growers, students, or distributors who are involved in the fruit chain.

\section{Portable and non-destructive equipment for fruit quality} assessment

A prototype of a portable, multi-sensor device for

\begin{tabular}{|c|c|c|c|c|}
\hline \multirow[b]{2}{*}{ Pillar } & \multirow[b]{2}{*}{ Focus } & \multicolumn{3}{|c|}{ Number of deliverables in each output category } \\
\hline & & $\begin{array}{c}\text { Scientific } \\
\text { knowledge }\end{array}$ & $\begin{array}{l}\text { Information of } \\
\text { consumer or } \\
\text { political interest }\end{array}$ & $\begin{array}{c}\text { Industrial } \\
\text { application }\end{array}$ \\
\hline 1 & Consumer-driven and responsive supply chains & 16 & 21 & 0 \\
\hline 2 & Fruit and human health & 45 & 6 & 0 \\
\hline 3 & Improving the appeal and nutritional value of processed fruit & 100 & 7 & 28 \\
\hline 4 & Quality, safety and sustainability: improved post-harvest chain management & 20 & 2 & 3 \\
\hline 5 & Quality, safety and sustainability: improved pre-harvest chain management & 44 & 3 & 9 \\
\hline 6 & Genetics of fruit quality and implementation of better fruit cultivars & 108 & 5 & 0 \\
\hline TOTAL & & 333 & 44 & 40 \\
\hline
\end{tabular}


non-destructive measurement of the quality status of apples and peaches is being developed. This device should allow measurements to be made in all situations, and under all conditions in the fruit supply chain. This prototype will incorporate a combination of existing techniques (e.g., near infrared spectroscopy (NIR), acoustic sensors, and colormetric assessments) that have been conveniently adapted to predict apple and peach quality more accurately. This prototype would need further development before it would be suitable to be commercialised.

\section{Fruit components used to lower cholesterol levels}

This task has identified apple components that reduce and/or equilibrate cholesterol levels in the blood, and have the potential to provide guidance for the fruitprocessing industry. Researchers have reported promising results related to the identification of these apple components, but validation of the results is needed.

\section{Production of dried fruits by optimised combined processes (osmotic dehydration and drying or freeze- drying)}

A technique is being developed to optimise the processing of fruits using osmotic dehydration in combination with drying or freeze-drying. This technology is currently being evaluated for commercial exploitation by the partners involved in this task.

Crop adapted spray application (CASA) system A system will be developed which will consist of:
- A crop identification system (CIS) to adjust spray application to the characteristics of the target;

- A crop health sensor (CHS) to identify tree health status to determine pesticide application rates; and

- An environmentally dependent application system (EDAS) to adjust the spraying equipment according to environmental circumstances.

The EDAS system has been protected, but industrial partners are needed to develop the system for industry.

\section{Decision-support tool for economical decisions in farm management}

A user-friendly IT-model has been developed to simulate economic scenarios at the orchard and variety level. This model evaluates the production costs of apples in selected European growing zones and helps farmers to choose the right strategy for their production. With the model, it is possible to develop a risk profile based on real world data for comparing farm management factors in terms of their impact on success if changes are made. This IT-model needs to attract venture capital to be commercialised.

The commercialisation pathways for these ten innovations from the ISAFRUIT Project are summarised in Table II.

\section{DISCUSSION}

The majority $(79.86 \%)$. of the deliverables promised in ISAFRUIT were focussed on providing additional scientific knowledge. Much of this knowledge could be of direct use to growers or others in the fruit supply chain,

TABLE II

An analysis of the innovation processes of ten selected ISAFRUIT inventions

\begin{tabular}{|c|c|c|c|c|c|c|c|c|c|c|c|c|c|c|c|c|}
\hline \multirow{2}{*}{$\begin{array}{l}\text { Innovation } \\
\text { No. }\end{array}$} & \multirow[b]{2}{*}{ Invention } & \multicolumn{4}{|c|}{ Exploitation model ${ }^{*}$} & \multicolumn{5}{|c|}{ Innovation stage $^{* *}$} & \multicolumn{6}{|c|}{ Added-value ${ }^{* * *}$} \\
\hline & & I & II & III & IV & 1 & 2 & 3 & 4 & 5 & $\mathrm{a}$ & $\mathrm{b}$ & c & d & $\mathrm{e}$ & $\mathrm{f}$ \\
\hline 1 & $\begin{array}{l}\text { New fruit products with added } \\
\text { nutraceuticals using freeze-chill } \\
\text { and vacuum processing }\end{array}$ & & & & $\times$ & & & & & $x$ & & $\times$ & $\times$ & & & \\
\hline 2 & $\begin{array}{l}\text { New fruit products using } \\
\text { microwave processing }\end{array}$ & & & & $x$ & & & & & & & & $\times$ & & & \\
\hline 3 & $\begin{array}{l}\text { New fruit products using } \\
\text { high pressure processing }\end{array}$ & $\times$ & & & & & & $\times$ & & & & $x$ & & & & \\
\hline 4 & $\begin{array}{l}\text { Alternative techniques to reduce } \\
\text { food-borne pathogens }\end{array}$ & & $\times$ & & & & $\times$ & & & & & & $x$ & $\times$ & $\times$ & \\
\hline 5 & $\begin{array}{l}\text { Prototype of decision-support } \\
\text { system for fruit quality } \\
\text { management }\end{array}$ & & & $x$ & $\times$ & & & $x$ & & & & $\times$ & & & & $x$ \\
\hline 6 & $\begin{array}{c}\text { Portable and non-destructive } \\
\text { equipment for fruit } \\
\text { quality assessment }\end{array}$ & & & & $\times$ & & & $\times$ & & & & & $x$ & & & \\
\hline 7 & $\begin{array}{l}\text { Fruit components to reduce } \\
\text { high cholesterol }\end{array}$ & $\times$ & & & & $\times$ & & & & & & $\times$ & & & & $x$ \\
\hline 8 & $\begin{array}{l}\text { Production of dried fruits by } \\
\text { optimised combined processes } \\
\text { (osmotic dehydration and drying } \\
\text { or freeze drying) }\end{array}$ & $\times$ & $\times$ & & & & & & $\times$ & & & & $x$ & & & \\
\hline 9 & $\begin{array}{c}\text { Crop-adapted spray application } \\
\text { system (CASA) }\end{array}$ & & $\times$ & & & & & $\times$ & & & $\times$ & & & & & \\
\hline 10 & $\begin{array}{l}\text { Decision support tool for } \\
\text { economical decisions } \\
\text { in farm management }\end{array}$ & & & $\times$ & $\times$ & & & $\times$ & & & $\times$ & & & & & \\
\hline \multirow{2}{*}{\multicolumn{2}{|c|}{$\begin{array}{l}\text { Total } \\
\text { Percentage }(\%)\end{array}$}} & 2 & 4 & 2 & 5 & 1 & 2 & 5 & 1 & 1 & 1 & 4 & 6 & 1 & 2 & 2 \\
\hline & & 15 & 31 & 15 & 38 & 10 & 20 & 50 & 10 & 10 & 6 & 25 & 38 & 6 & 13 & 13 \\
\hline
\end{tabular}

"Exploitation Model: $\mathrm{I}$ = trade secret; II = patenting or registering; III = copyright; IV = publication/free access.

** Innovation Stage: 1 = basic research; 2 = proof of concept; 3 = early-stage technology development; $4=$ product development; 5 = production marketing.

***A Added value: $\mathrm{a}=$ production cost savings; $\mathrm{b}=$ possible launch of a new product to market; $\mathrm{c}=$ improvement of existing product; $\mathrm{d}=$ overcoming legal restrictions; $\mathrm{e}=$ environmental and societal goals; $\mathrm{f}=$ other. 
and some is being transferred through grower workshops. The remainder will be transferred to other scientists through scientific papers which will, in turn, assist with new technological developments in the future.

Of the potential innovations listed, $80 \%$ were found in Stages before the "valley of death", therefore their impact on the market cannot be predicted. Where partnerships between researchers and commercial companies existed during the development of an innovation, the development process has progressed closer to Stage 5 in the innovation pathway. This is not surprising according to other evidence. Such partnerships bring new ideas to meet the needs of the market-place and are more likely to bridge the "valley of death" (Marczewski, 1997; Wessner, 2005). Markham (2002) identified that "product champions" were essential in order to move technologies from the laboratory to the market, and that the "champion" needed to follow a number of steps to succeed. Thus, including a commercial partner from an early stage in the innovation process makes it more likely that the idea or product will be of commercial value. However, it can be difficult for industry to be interested in any technology that has broad societal goals such as human health or environmental benefit, as any industrial focus is related more to raising performance and lowering costs (Marczewski, 1997).

Bagnara (2002) identified the value of interactions between science and industry in increasing innovation. He quoted a report that showed that higher levels of interaction occurred between scientists and industry in certain cases, including where there was a market demand for new technology, incentive schemes, and/or policies for scientific institutes to engage with industry, and where legislation did not constitute a barrier to engagement.

Another issue that reduces the impetus for the commercialisation of innovations is the scientific career pathway. Scientific publication is still the major element for promotion and remuneration within the science system, and the widely accepted way to measure performance (Butler, 2002; Taylor and Barrett, 1997). A survey carried out in Australia by Shewan et al. (2005) indicated that publications were viewed as being more important outcomes of research than patents or commercial products by over 500 health and medical researchers. Indeed, a person's publication record is the key criterion for many research-funding schemes. Therefore, this continues to fuel the drive by scientists to publish (Butler, 2002). However, Guasch (2007) declared that this situation has been changing and that patents are becoming progressively more important in basic research as well as in applied research.

Other obstacles that have hindered the pathway to patenting in the ISAFRUIT Project have become evident. First, the complexity of the EU patent system makes it difficult for scientists to know if their research will or will not be potentially patentable. Second, the system used in collaborative EU Projects (e.g., in the Sixth Framework Programme), where new knowledge and/or innovations are the result of collaborations between several partners, means that Intellectual Property Rights (IPR) management becomes a complex issue, and agreements between partners are often difficult to reach, particularly since IPR was not discussed for each individual new or unforeseen technology at the start of the Project. These reasons may explain why so few patents can be expected as outputs from the ISAFRUIT Project.

One innovation (ID 1; Table II) has reached Stage 5. In this case, no protection or the trade secret route was chosen. This development was carried out in close collaboration with a Company that owned the product involved in the new development. The involvement of the Company for exploitation during the research and development phase explains why maximum diffusion of the results was achieved. Marczewski (1997) believed that the development of technology involving privatepublic co-operation, such as in this case, can result in successful bridging of the "valley of death". The most appropriate form of protection still needs to be identified for another technology that appears to have passed successfully over the "valley of death" (innovation Stage 4; ID 8; Table II).

Another innovation arising from the ISAFRUIT Project, which has proceeded further than anticipated, is the Decision Support System (innovation Stage 3; ID 5; Table II). This technology was initially developed to add value in the academic world as a tool to teach students about the importance of decisions taken along the fruit chain, in relation to final product quality. However, it was decided to exploit the tool commercially, mainly to reach the greatest number of people. There are now plans to keep the DSS updated after the ISAFRUIT Project has finished.

There is evidence for some success in the development of innovations arising from the ISAFRUIT Project, with several further innovations in the pipeline. There is also an opportunity to learn from those issues that have prevented a greater number of patents being filed and innovations commercialised, and to initiate better planning when developing future programmes. Inclusion, where possible, of industry partners would be a valuable step towards ensuring industry uptake. Consultations with industry, before project development, would at least ensure that it might proceed in a direction that would be more likely to move over the "valley of death". For each planned innovation, the partners involved should agree upon the specific IP arrangements and on a possible IP protection strategy. A plan for IP protection and an understanding of when publications will be possible, also needs to be agreed.

The ISAFRUIT Project is funded by the European Commission under Thematic Priority 5 - Food Quality and Safety of the 6th Framework Programme of RTD (Contract No. FP6-FOOD-CT-2006-016279).

Disclaimer: Opinions expressed in this publication may not be regarded as stating an official position of the European Commission. 


\section{REFERENCES}

Anon. (2009a). What is intellectual Property? World Intellectual Property Organisation. (http://www.wipo.int/about-ip/en/).

ANON. (2009b). How can I manage the IP related issues in an EU project? IPR-helpdesk website (http://www.ipr-helpdesk.org/ documents/ES_tradesecret_UJ_en_final_0000006449_00.xml. html)

ArChibugi, D. (1992). Patenting as an indicator of technological innovations: a review. Patenting, 19, 357-368.

Bagnara, G. L. (2002). Innovation policy and key issues of the horticultural system. Chronica Horticulturae, 42, 25-31.

Branscomb, L. M. and Auerswald, P. E. (2002). Understanding early-stage technology development. In: Between Invention and Innovation. An Analysis of Funding for Early-Stage Technology Development. 27-56. (http://tsapps.nist.gov/ts_sbir/resources/ gcr02-841.pdf)

BUtLER, L. (2002). A list of published papers is no measure of value. Nature, 41, 877-876.

Daizadeh, I., Miller, D., Glowalla, A., Leamer, M., Nandi, R. and NUMARK, C. (2002). A general approach for determining when to patent, publish, or protect information as a trade secret. Nature Biotechnology, 20, 1053-1054.

GuASCH, L. (2007). Nuevas perspectivas en la evaluación de las patentes como parte del curriculum científico. Revista española de Documentación Científica, 30, 218-240.

Heanue, K. (2008). Innovation on Irish farms. Research and Innovation News at Teagasc, 3, 39-40. (http://www.teagasc.ie/ publications/tresearch/tresearch200808.pdf).
KALANJE, C. (2005). Role of intellectual property, innovation, and new product development. $10 \mathrm{pp}$. (http://www.wipo.int/sme/en/ documents/ip_innovation_development.htm)

MARKham, S. (2002). Moving technologies from lab to market. Research-Technology Management, 6, 31-42.

MARCZEWSKI, R. (1997). Bridging the Virtual Valley of Death for Technology R\&D. The Scientist, 11, 11-15.

OECD. (1997). Innovation Manual: Proposed Guidelines for Collecting and Interpreting Technological Innovation Data (Oslo Manual). Directorate for Science, Technology and Industry, Organisation for Economic Co-operation and Development, Paris, France. 92 pp

Rogers, M. (1998). The Definition and Measurement of Innovation. Melbourne Institute Working Paper No. 10/98. 27 pp. (www.melbourneinstitute.com/wp/wp1998n10.pdf).

Shewan, L. G., Glatz, J.A. Benett, C. C. and Coats, A. (2005). Contemporary (post-Wills) survey of the views of Australian medical researchers: importance of funding, infrastructure and motivators for a research career. Medical Journal of Australia, 183, 606-611.

TAYLOR, I. E. P. and BARRETT, K. J. (1997). To publish, or patent, or both? Ethical issues surrounding publication and exploitation in plant biotechnology. Plant Physiology, 114 (3: Supplement), 307.

WeSSNER, C. W. (2005). Driving innovations across the valley of death. Research-Technology Management, 48, 9-12. 